\title{
WINE CULTURAL LANDSCAPE AND VERNACULAR TYPOLOGIES IN SOUTH- WESTERN IBERIA: THREE CASE STUDIES IN ALENTEJO AND ANDALUSIA
}

\author{
A. C. Rosado ${ }^{1,2, *}$, J. M. Aladro-Prieto ${ }^{3}$, M. T. Pérez-Cano ${ }^{4}$ \\ ${ }^{1}$ CEAACP/Mértola's Archaeological Field (CAM), Portugal - ana.costa.rosado@gmail.com \\ ${ }^{2}$ Heritage and Urban Territorial Development in Andalusia (HUM700). ETSA, University of Seville, Spain \\ ${ }^{3}$ Dept. of Architectural History, Theory and Composition. ETSA, University of Seville, Spain - aladroprieto@us.es \\ ${ }^{4}$ Dept. of Urbanism and Regional Planning. ETSA, University of Seville, Spain - tpcano@us.es
}

Commission II - WG II/8

KEY WORDS: Winery, Traditional architecture, Industrial building, Cultural landscape, Southern Iberian Peninsula

\begin{abstract}
:
In the Mediterranean scenery of the south-western Iberian Peninsula, vineyards and wine-making have consistently been key pieces of the man-made cultural landscape, influencing urban design and even housing. This paper compares wine production influence in the cities of Borba, in Portuguese Alentejo, Jerez de la Frontera and Bollullos Par del Condado, in Spanish Andalusia, throughout the spheres of territorial organization, urban layout, presence of production buildings inside urban areas, and winemaker and wineworker housing. The study is based on architectonic surveys of building types: wineries, dwellings and houses with integrated wine production on both sides of the Guadiana River. The information gathered in surveys is complemented with data from historical documents, such as transaction records from the 16th to the 19th centuries. The research analyses cycles of prosperity for the three case studies - which are often coincident and related, within the frame of pre-industrial global trade - and the effects of those in winery and housing typologies. Across the studied area, vernacular winery types adhere to the same two categories, or typological lines, of building: the domestic winery and the autonomous building. Wine related architecture is still a key asset in these cities' material and cultural heritage, as it provides scale and uniqueness to the urban and rural ensembles, despite the fact that wineproduction has been removed from cities' centres to outer industrial wineries. The memory of wine-induced prosperity is imprinted on the cities' physical realities, giving meaning to their collective memories and proving to be an asset to future development.
\end{abstract}

\section{INTRODUCTION}

Wine and vine culture in the Western Mediterranean scenery has been a piece of man-made landscape since time immemorial. It appears in the form of linear-designed vineyards and has also helped shape building typologies in rural and townscape wine-producing cities. These typologies include wineries, houses with wine production, workers' dwellings,... all of them being key pieces in the urban construction of winecities. This paper confronts three distinct cases of wineproducing cities on South-western Iberia - Borba, in Portuguese Alentejo, Jerez de la Frontera and Bollullos Par del Condado in Spanish Andalusia - and describes their wine-related built heritage. The research was based on in loco architectonic and photographic surveys of the buildings, subsequently complemented with data from historical archive documents, such as transaction records - records of the acquisition and sale of properties, often containing descriptions of the buildings involved in the transaction - from the 16th to the 19th centuries. The three case-studies are geographically and climatologically close, having many of the landscape features associated with the Mediterranean world, and share strong cultural ties. The main difference between the three cases relates to the scale of production and consequent velocity in the industrialization transition, which will mean disparities in vineyard-town relation and building typologies used in wine production.

Traditional wine-making processes depend on vines planted in the vicinity of settlements, in plots of relatively small dimensions. Even with the Liberalism-age concentration of property, vineyards were never comparable in size with cereallatifundium type of agriculture holdings. Grapes picked at the end of summer were carried into the urban areas, to buildings ready to receive and process them, mainly in compartments inside winemakers' houses. There, they would be treaded and the resulting juice would be kept in clay vessels to ferment (clay vessel prevailing in southern latitudes and wooden barrels predominantly being used above the Tagus River (Ribeiro, 1961, p. 47). Although transversal to the Iberian Peninsula, vines are prone to flourish in, generally small, areas that combine soil and climate-appropriate characteristics - plenty of sun, mild spring temperatures followed by hot and dry summers, adequate soil drainage - and therefore produce exceptional quality wine. These areas will be the ones that, in between medieval and modern areas, will outgrow selfconsumption and start supplying neighbouring cities (Simões, 2007, p. 22). Eventually said commerce routes can develop to national and potentially international scales (Borrero Fernandéz, 1995, p.58). These areas' centuries-old reputation of wine excellence is today recognized in Protected designation of origin delimitations (DO/DOC).

The growth in production of these singular areas, during the Modern Age, will make them experience first-hand deep transformations on the wine-making process which will lead to industrialization. The transition from a traditional to an industrial (or capitalist) model of production carried out during the $18^{\text {th }}$ and $19^{\text {th }}$ centuries will entail changes in building typologies and townscapes. Moreover, it will bring changes in the economic and social structures of wine-making and its subsequent culture.

* Corresponding author 
Those structures and cultural bonds can still be found at present in these wine-making communities and form a major part of their social traditions and cultural heritage. The ensemble of built and cultural heritage encompasses productive systems, knowledge and customs, ways of life and relation with the environment. As the majority of the rural world, nowadays these areas face depopulation and impoverishment and it is, therefore, crucial to value their heritage and highlight their cultural legacy, not only for future memory but also for future opportunities.

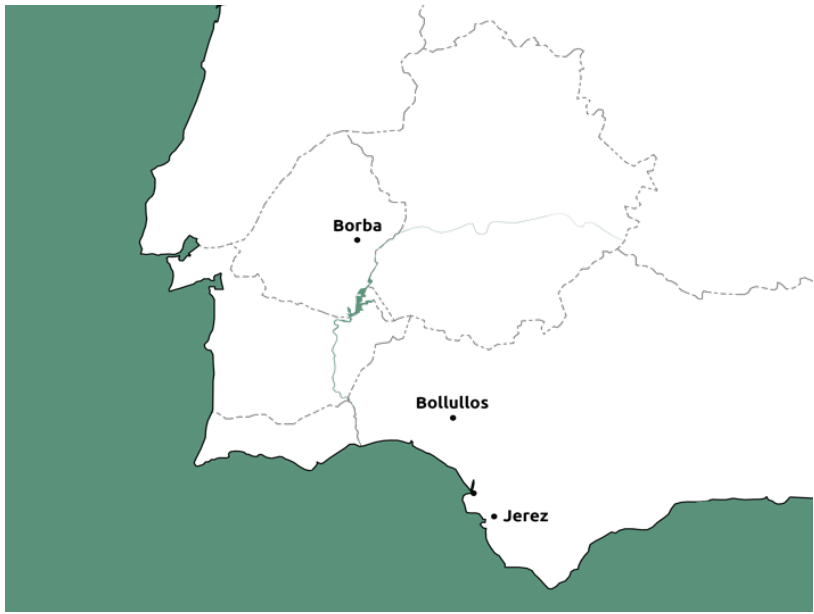

Figure 1. Case studies in the south-western Iberian Peninsula. (Rosado, 2020).

\section{EXPERIENCES}

\subsection{Borba: exceptionality within tradition}

\section{Main Typology: urban winemaker house}

Borba, in Portuguese Alentejo, is an example of prosperity in the traditional model of production. During medieval times, its situation did not differ from that of its neighbours: wine was made for self-consumption, at houses of vineyard owners. It is during the 17th century that Borba's wines, with a growing reputation of quality, begin to supply its neighbour cities and become the major asset for the town's economy (Simões, 2007, p. 21). Gradually, wine profits resulted in the conversion of other cultures into vineyards, reaching a situation close to monoculture, with high levels of economic dependency on wine. Nevertheless, the culture thrived and the $18^{\text {th }}$ century was marked by prosperity. Borba's townscape still reflects today the Enlightenment Age auspicious decades, in its urban planning and civil architecture (Rosado, Reimão, 2019, p. 46).

The large scale of production, in relation to the city's size, did not, however, lead to transformations in the traditional production system. Vineyards were planted on the immediate city's surroundings, in generally small plots. Property was very divided, with one producer owning one or several small plots of vines. The vicinity of the vineyards made it easy for the transformation of grapes to be done inside the urban sphere, at each producer's house. The increase in wine quantity in Borba was achieved by turning what was the norm at the time - a few producers in a town - into a generalization, with the majority of farmers producing wine. Winemaking became a city-wide activity and the majority of homes had winemaking or storage compartments.

This production system created its own spaces of fabrication and led to building typologies very characteristic of the city.
The most commonly found is the winemaker house. This type of family dwelling is identified by the segregation of production and storage areas and residence ones, in the ground and the upper floor, respectively. The sixteen hundreds' winemaker house is one of moderate dimensions, with generally two floors. Historical archive records of 1627 to 1635 describe houses with wineries as having three to five compartments on the ground floor, 1-2 upper floor rooms, and normally a backyard (Rosado, Reimão, 2019, p. 49). One record, in 1628, mentions for the first time a corridor, an important element in the transition from house front to backyard, which will be a key piece in the winemaker house type definition.

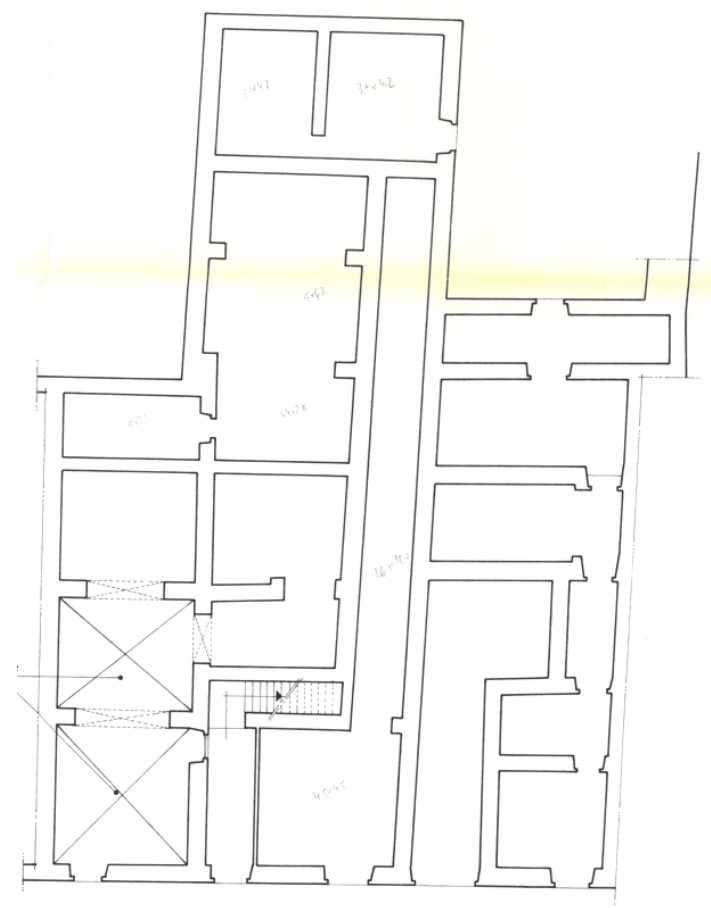

PLANTA DO R/C

Figure 2. House in Largo dos Combatentes, 25, Borba. (Municipal Archive, Borba).

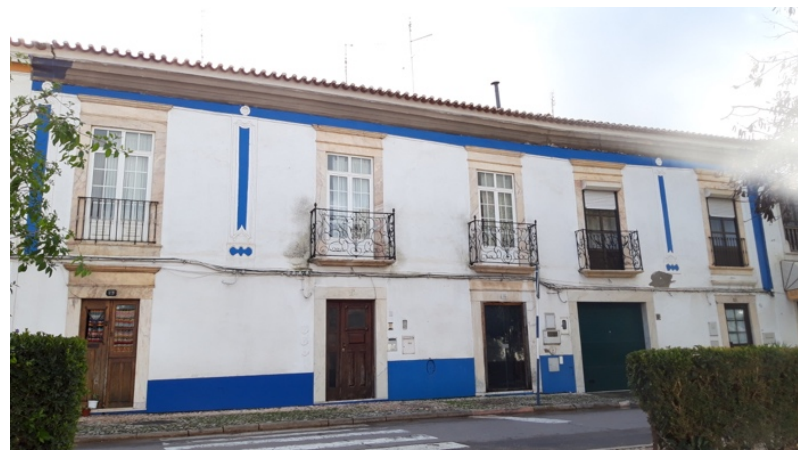

Figure 3. Façade of house in Largo dos Combatentes, 25, Borba. (Rosado, 2020).

The growth in production at the turn of century correlated directly with the growth in size of houses. The examples dated from the $18^{\text {th }}$ century display an ennoblement process, reflecting the rise in wealth and social standing of its owners. On the ground floor, a new layout marks the new house-type specifications - the entrance is done through a distribution hall, from where there is access to the stairway leading upstairs, where the residential areas are located. 
The entrance hall also leads to a long corridor, which ensures direct connection with the backyard. There is an increment in production and/or storage compartments in comparison with the earlier winemaker houses (Figure 2). Most importantly, the ground-floor ceilings are almost always brick vaults, supported by brick arches and pillars (Figure 4), to ensure the widest open space possible. As regards those ground floor compartments, it is worth highlighting the room for treading grapes, which displays a floor paved with large marble slabs with a slight inclination towards the centre of the room. The inclination allows for grape must to be directed into an underground deposit. From there, wine is transferred into clay vessels in order to undergo the fermentation process (Figure 4). In case a vessel would break, the room configuration would make the wine slide back into the underground deposit, and it would not be lost. It was also frequent to see a tavern connected to the winery, to sell wine to the public. The tavern (taberna) was then Borba's most important space in social identity, although it was an exclusively male space. Gathering and drinking at taverns were marked by rules and customs significantly responsible for the creation of deep social and cultural bonds during the past centuries (GTL Borba, 2001, p. 53).

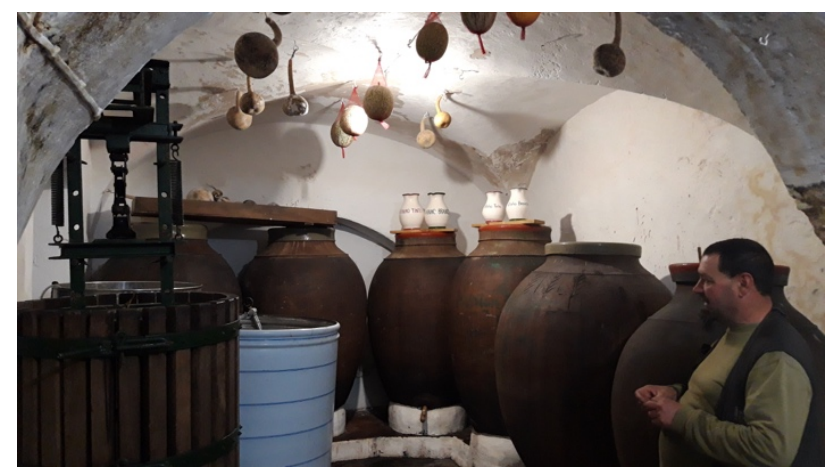

Figure 4. Wine clay recipients in a tavern. Rosado, 2020.

The upper floors of these houses present akin features, with the staircase positioned parallel to the main facade and ending at a distribution landing. At the landing's right side stands the social area: generally three square-shaped rooms, with balconies opening to the street. At the landing's left side stands a deep corridor, mimicking the one beneath, which leads to the functional and service areas of the house kitchen and inner bedrooms (Figure 5). Variations of this type relate mostly to the size of houses, reflecting different levels of prosperity inside the winemakers' class. Also in the 18th century, common houses, or those which agglutinated several small houses, were given new façades, as part of a stylistic ennoblement process, where local marble stone played a major role. Uniformisation and valorisation of the façade were done with baroque style pilasters and cornices of stucco, and window-, door-frames and balconies of local white marble.

After the mid-19th century, the concentration of property in a few individuals and the large losses deriving from the filoxera plague, led to the end of the traditional winemaking system. The city's economy would not recover until mid-20th century. Nowadays, Borba's winemaking evolved into the industrial model with the particularity of centralizing production in a cooperative winery, re-establishing a model of dispersed property and wide distribution of profits that so greatly benefited the city two centuries ago.

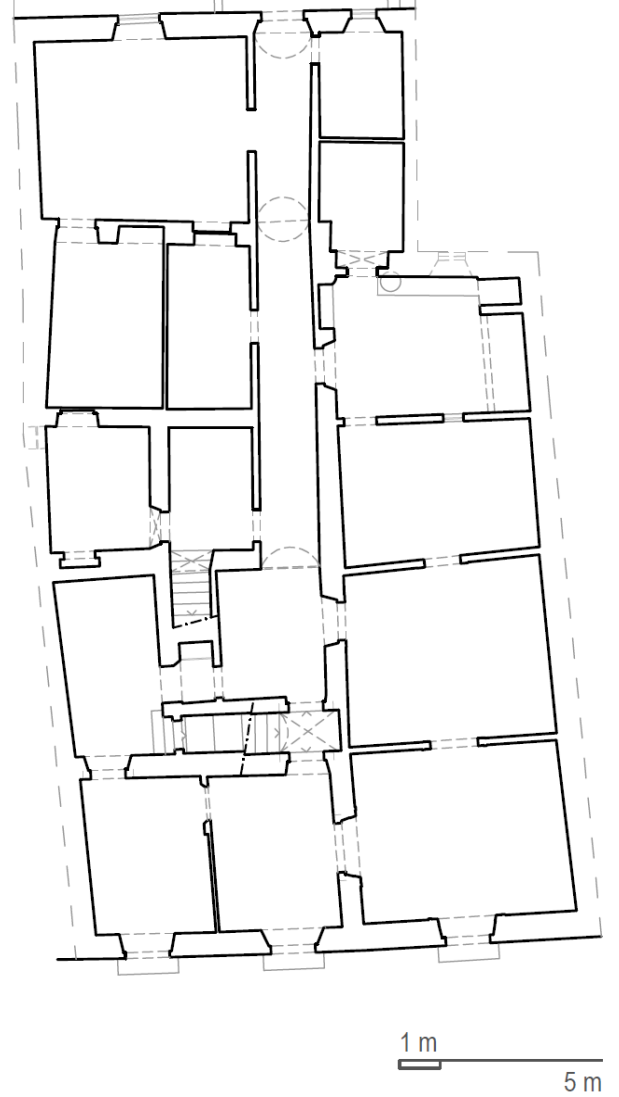

Figure 5. House in Rua de S. Bartolomeu, 21. (Drawing: Rosado, 2019).

\subsection{Jerez: scale and innovation}

Main Typology: dual system with rural winery house and urban warehouse

Jerez de la Frontera and its surroundings (from now on referred to as Marco de Jerez) show an exceptional situation in wine production and massive scale export trade. During the late $15^{\text {th }}$ century and the whole 16th century, Andalusian wines benefited from growth in the internal consumer market, and the beginning of exportation, firstly to some European countries and, afterwards, to the newly opened colonial market in America (Iglesias Rodríguez, 1995, p. 68). Jerez wine was one of various in Andalucía to rise in reputation and, especially, in quantity, with a frequent surplus in production. The surplus in quantity directed Marco de Jerez' producers into exportation from a very early stage. By the 17 th century, exportations were consolidated, and, regarding sales to the British market, benefited from tax increases and occasional embargoes on French wine. At the beginning of the 18th century, Jerez would be a player at the European scale and necessarily important transformations in the production system had to occur. Winemaking evolved definitely into an industry of capitalist contours and, by the last third of the 18th century, the traditional winemaking process was, in Jerez, completely surpassed (Aladro-Prieto, 2012, p. 85). This period between the mid- $18^{\text {th }}$ century and the end of the 19th century can be considered as Jerez' development period, or, more lyrically, Jerez' golden age, as it is the time when the city consolidates itself in all its scales - economic, urban,... - as a winery city and during which the area of vineyard plantations duplicated (Aladro-Prieto, 2009, p. 36). 
The consequences of the economic transformations were seen in the production spaces. The much larger amounts of wine produced needed an exclusive space and, consequently, the winery typology adapted and consolidated itself. On the preindustrial period, there were found in the Marco de Jerez a series of coexistent winery typologies, some of which industrialization would render obsolete. Noble homes and convents would possess compartments to store wine, and houses with a winery would be found until the 19th century, although in residual numbers considering Jerez' total record of wineries. There were wineries associated with barns, and there could be found small autonomous wineries based on a constructive system of modular distances of pillar rows and gabled roof. It is the latter constructive typology that would be predominantly used in the capitalist age (Aladro-Prieto, 2012, p. 161), although, until the 19th century, it would still share protagonism with other minor distribution typologies.

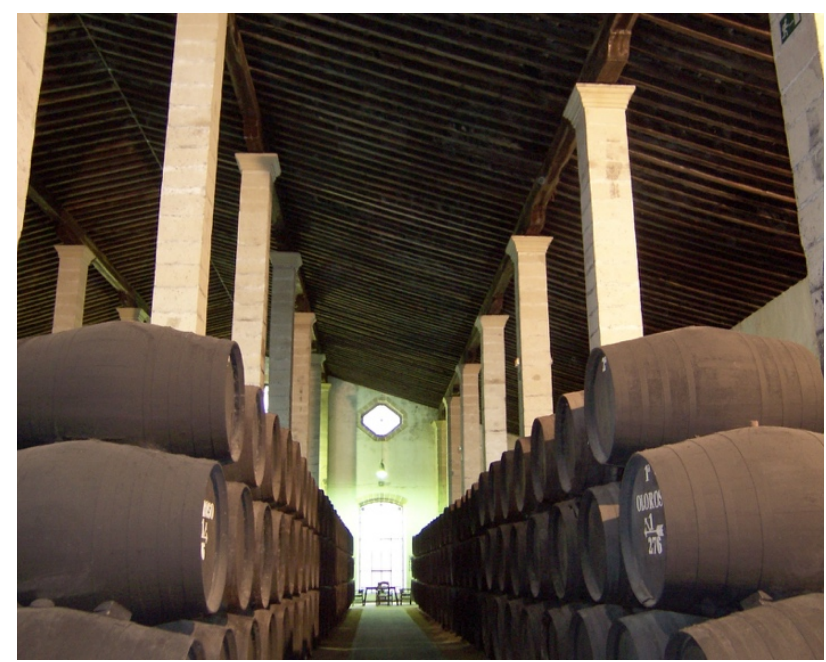

Figure 6. Winery Dios Baco, Jerez de la Frontera. (AladroPrieto, 2012).

This module-based model of autonomous winery is always located above ground and can be found in two types, as far as the composition layouts are concerned: cloister wineries, where aisles were arranged around a central courtyard, and basilical wineries, where space was confined to a single building of longitudinal plant (Aladro-Prieto, 2012, p. 173). The plants were divided into parallel aisles by pillars of stone or brick connected in archway lines. These support gable roofs made of timber rafters covered by tiles, limestone mortar, and semicylindrical roof tiles. The exterior walls combine stone and brick in approx. $60 \mathrm{~cm}$ thickness and are covered with white limestone renders to reflect sunlight. Pavements are made of compact sandy earth, or albero. Preferentially, its implantation was done in East-West orientation, as to avoid southern exposition, and the consequent excessive rise of the inner temperature. Also, it benefits from the humid western (Atlantic) winds to keep inner relative humidity above 50\%, which is, alongside temperatures between 12 and $25^{\circ} \mathrm{C}$ and a good ventilation, generally considered to be the ideal conditions for the vinification process. The basilical type would be the one to gain prominence throughout the 19th century, as, likely, it was the type best fitting the needs of maximization of the industrial economy. During that century, the basilical typology would evolve in scale and height, and face a process of standardization and optimization of space and material usage which made it one of the most polished vernacular production typologies.

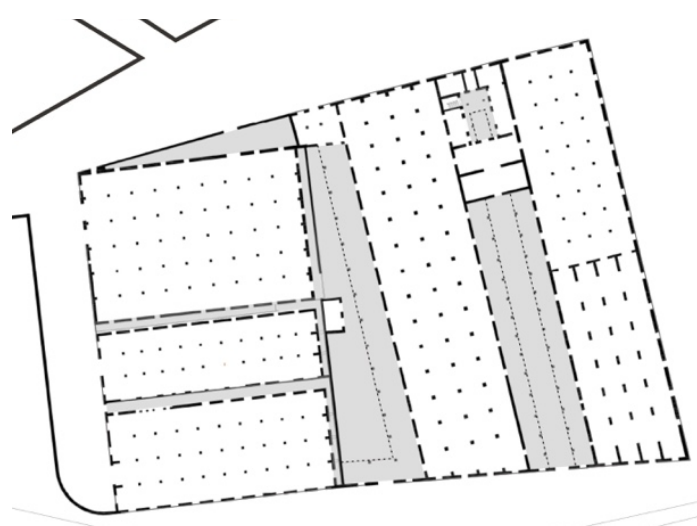

Figure 7. Basilical plant example. (Aladro-Prieto, 2012).

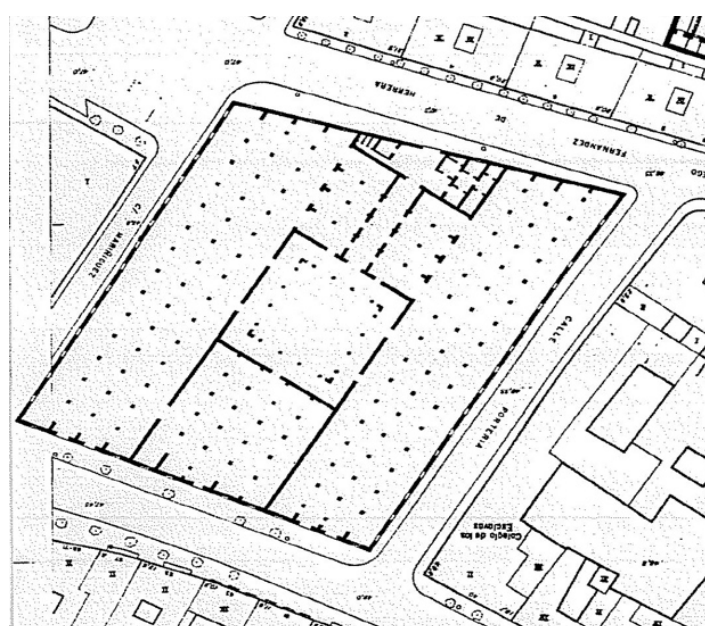

Figure 8. Cloister plant example. Bodega El Cuadra, 1810-1819. (Delegación Municipal Urbanismo, Jerez de la Frontera, 1979).

But the Jerez' wineries have a more significant particularity: the very frequent inexistence of winepresses. Those were located at the vineyards themselves, as part of two-part winemaking process combining rural and urban spheres. The grape must was obtained from treading grapes directly at the vineyard house, casa de viña, the first step in the production chain. Vineyard houses with winepress to obtain wine must avoided the transport of grapes into town, processing them while at their utmost freshness. The vineyard house is a highly functional structure, typically located on hilltops (Olmedo Granados et al., 2002 , p. 60). Like its urban counterpart, it consists of a single building, very rational and modular, which hosts three functions: grape-treading, small storage of wine must and workers' room. The spaces corresponding to each of these functions are generally laid out side by side, with the inner space divided by walls or pillar rows (Aladro-Prieto, 2009, p. 52). The most distinctive element of this typology is the front porch: standing over archways, it protects the house from sun and rain. Exterior load-bearing walls could be erected using rammed-earth while employing local stone in structural key elements as corners or door frames. Roofs are made of timber structures, often gabled, and pavements are, like urban wineries, of albero earth (Olmedo Granados et al, 2002, p. 64). The vineyard house was never a piece that operated independently within the production system. Although its origins can be traced back to smallholding agriculture, that economic model disappeared from the Marco de Jerez to be replaced, from the 
mid-18th century onwards, by a capitalist model of property concentration in a few large vertical companies (Maldonado Rosso, 2019, p. 13). The concentration of property and control over all steps of production and trade meant that the winemaking company would encompass the land, the vineyards' houses, and the urban wineries/warehouses inside the same, almost inseparable, entity. The casa de viña spread during the 19th century across the fields of Marco de Jerez - from 555 in 1792 to 826 in 1839 (Aladro-Prieto, 2009, p. 49) - but estate manors were rare to find, probably because the vineyards' proximity to town made it unnecessary to have lodgings for the landowner so close to the city.

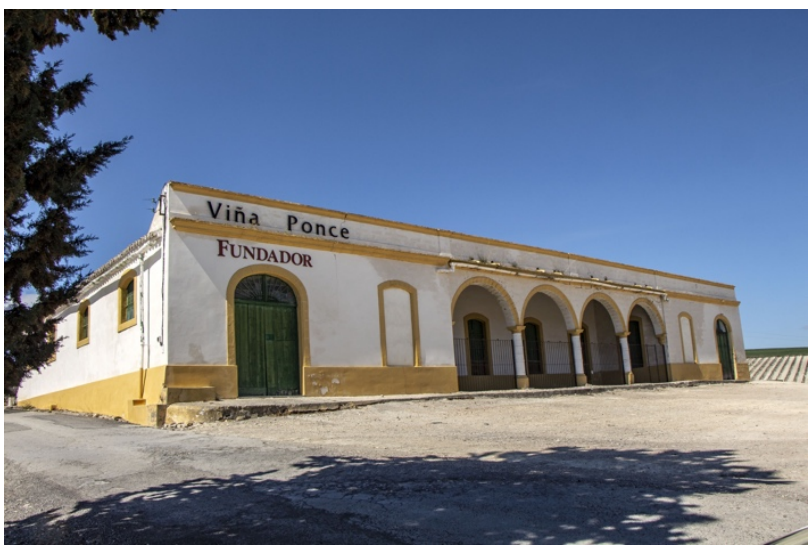

Figure 9. Casa de viña. Viña Ponce, Jerez de la Frontera. (Agustín and José García Lázaro).

Inside town, wineries were transforming the urban scenery, reaching an impressive percentage of urban soil occupation. Jerez was, at the beginning of the 19th century, a sprawling city, oversized for its population figures at the time. The urban mesh contained many empty areas and ruined plots, which would serve the construction of wineries and wineries' complexes without having to further expand the city (AladroPrieto, 2012, p. 438). The industrial building would be a key piece in shaping the city's morphology, especially the vectors leading outside the city, as roads or the railway surroundings (Aladro-Prieto, 2012, p. 491). Although mixing with residential areas, on the south-south-western city's limit, wineries would create a border area and scenic backdrop to receive newcomers to Jerez.

As we have seen in the previous example, a culture of wine drinking flourishes associated with the pivotal role of wine production in Jerez' way of life. Tabancos, taverns, proliferated inside the city to sell wine directly to the consumer and will be, like the already mentioned example of Borba, a place of masculine socialization, responsible for the establishment of social rites and the development of common social identity (Zafra Costán, 2009, p. 63). Those are, as the wineries, independent buildings of one-floor height.

\subsection{Bollullos: Modernizing on a small scale}

\section{Main Typology: Urban autonomous winery}

Jerez' prosperity reached its neighbouring winery surroundings, such as Sanlúcar de Barrameda or The County of Huelva (Condado). The increase in production scale in the 18th -19th centuries would encompass these cities and mean economic leverage to wine production. Bollullos Par del Condado, in the county of Huelva, was a winemaking area since ancient times and, by the end of the 15th century, it would be the Andalusian County with the highest wine production (Borrero Fernandéz, 1995 , p. 58). It benefited from ideal conditions for vineyard cultivation: plenty of sun, mild spring temperatures which rise in summer, a combination of sand and clay soils (Fourneau, 1975, p. 19). But while Jerez grew in modern times, Bollullos area became peripheral and part of its production was directed to supply Jerez, with the wine being re-labelled and sold by the great exportation centre.

However, thanks to a long tradition of winemaking, the Condado's wines kept their overall quality and reputation. Bollullos would remain inside the traditional production system until the 19th century - at the end of the 18th century, vineyards were only $18 \%$ of cultivated land (Fourneau, 1975, p. 47) -, when Jerezian influence would boost wineries' transformation and growth. Nevertheless, the process of industrialization would occur on a smaller scale. It would mean, for instance, that grape transformation would be made inside urban areas, given vineyards' proximity to town. Apart from the rarity of vineyards' houses in the Condado, and particularly in Bollullos (Fourneau, 1975, p. 34), the wineries of the area would follow Jerez' models, albeit being generally smaller buildings ((Díaz, 2003 , p. 131). The wine aged in oak barrels, so wineries needed to ensure the ambience conditions described in the previous point. Bollullos' wineries repeated the models of cloister or basilical types, with buildings of parallel aisles, divided by high brick archways supporting high ceilings of timber gabled roof structures covered by tiles, limestone mortar, and semicylindrical roof tiles. Brick whitewashed walls of $60 \mathrm{~cm}$ would keep the inner humidity levels around $50 \%$, with the aid of western winds - as the implantation of wineries in Bollullos consistently follows the East-West orientation (Díaz, 2003, p. 132) - and glassless high openings, sometimes shielded by wooden shutters. An example of cloister winery can be found at Clemente Neble, and a very early example of basilical winery is seen at Bodega Las Carrionas (Figure 10).

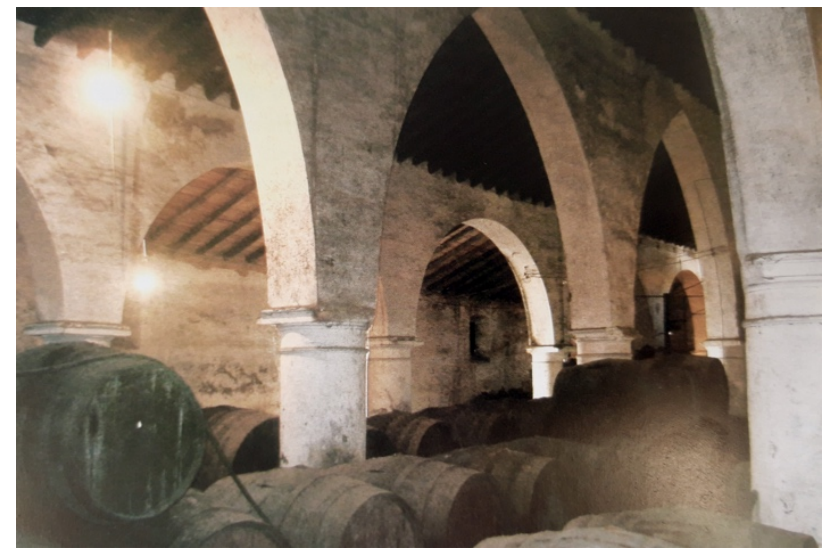

Figure 10. Winery Las Carrionas, Bollullos. (Díaz, 2003).

Again, like Jerez but on a smaller scale, the winery building would be a key piece in consolidating the urban mesh, and would, by the beginning of the 20th century, be the main factor driving the city's expansion. The fact that the construction of Bollullos' winery buildings would happen at a later stage than in Jerez would help to implement solutions already tested there and to reach optimized construction standards - essentially, to implement buildings closer to industrial models. More complex installations were formed through the agglutination of versatile modules, in a series of adjacent aisles. 
Before the arrival of the capitalist system in the 19th century, historic documents refer to the pre-industrialization use of clay vessels and manufacturing objects whose nomenclature is similar to what was found for Borba (Díaz, 2003, p.137; Rosado, Reimão, 2019, p. 50), asserting their relation to the Mediterranean traditional methods. Bollullos's vernacular housing models would show traces of traditional production even after the winery had moved out of the house. The generalised use of yards and winepresses was still seen both in erudite and common houses in the mid-20th century (Fourneau, 1975, p. 36). The most frequent type of common housing would have the entrance door opening to a corridor and two or three chambers on either one of its sides. The corridor would give direct access to a yard or courtyard, next to which stood the kitchen and, at the back, the winepress. Erudite houses would reiterate the use of inner courtyards, but with distinctive façades marked by entrance porticos topped by decorated balcony windows (Díaz, 2003, p. 70).

After the industrialization peak in the last third of the 19th century, boosted by exportations to French markets - the first to be affected by the filoxera plague -, Bollullos suffers a major drop, from which it would not recover until the 1920s. A very singular occurrence would, at that point, shape Bollullos throughout the 20th century: forest land underwent an important division in small plots, which were transformed in vineyards and distributed among farmworkers. It established a new and large class of small landowners (Fourneau, 1975, p. 61) and distributed wine profits among a large percentage of the population. Like Borba, Bollullos implemented a Cooperative model in 1955 that is still flourishing nowadays.

\section{DISCUSSION}

The comparative analysis of the three case studies showed similitudes in the spatial organization models used to shelter wine production, across the three geographical areas. As mentioned above, Bollullos' evolution is not independent from Jerez's influence, and therefore there is a correlation between the typologies used in both cases. Nevertheless, Borba's distance makes the case-study fairly unrelated, from an economic and administrative perspective, to the two latter, and it could have shown a completely different typological scenario. That is not the case as, for all the three case-studies, one can recognize the grouping of the different types of building along two fundamental typological lines: the winery as part of the house and as an autonomous building.

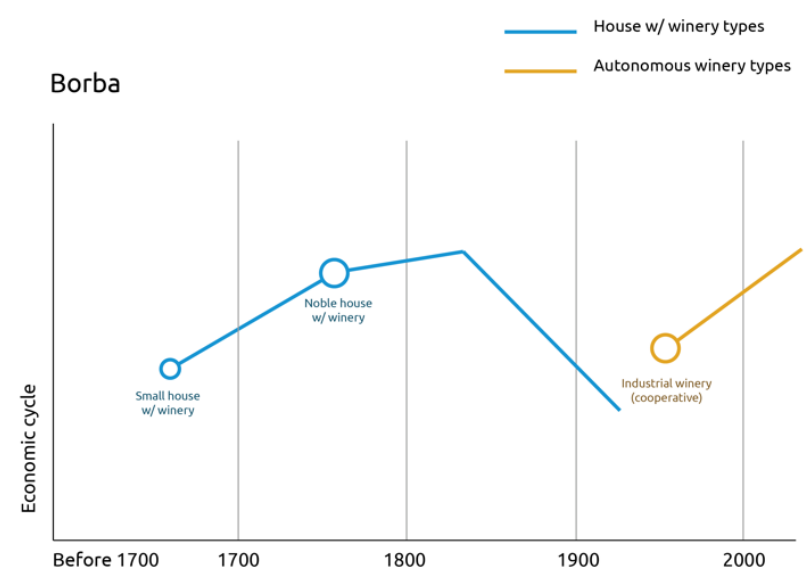

Figure 11. Chronological display of Borba's winery types, by typological line of evolution.
In Borba, the two lines were never coincident, as the autonomous winery was only established after the end of the traditional production system, and was never part of it. The peak in production reached in mid-19th century was supported by the production of wine inside houses, smaller or bigger, and taverns (Figure 11). The arrival of the autonomous winery building happens with the implantation of the Cooperative Winery.

In Jerez, on the other hand, the autonomous winery model appeared early, before the 18th century, and would consolidate itself in its two most significant types - basilical and cloister wineries - around the 1700's. During Jerez' Golden Age between the mid-18th century and the end of the 19th century the autonomous basilical winery would reach large dimensions and preponderance above all other types. Types of domestic winery would subsist until early 19th century but would never play an important part in Jerez' production, and there would be no evolution in the house with winery type (Figure 12).

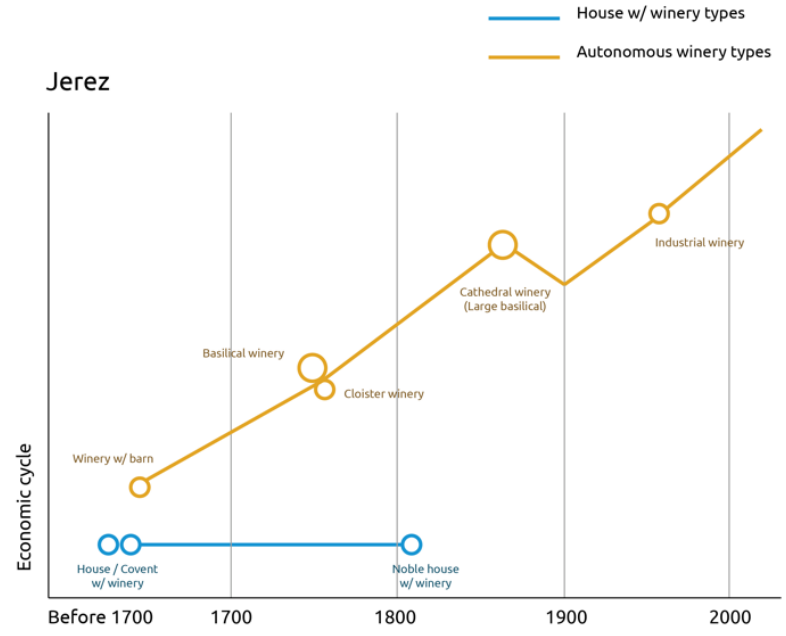

Figure 12. Chronological display of Jerez's winery types, by typological line of evolution.

Bollullos is the case-study where the two typological lines coexist for a longer time and with more balance. Wine production in Bollullos was traditionally based on the domestic sphere: wineries were integrated in the traditional common house, alongside barns or other agriculture-related facilities. This common house type with barn would change little across the years, and would be part of the wine production chains until the mid-20th century. The situation is reminiscent of the one in Borba: it is to be noticed that the similarity between the two cities' production models is probably due to their also similar urban dimensions and population figures. But in Bollullos, small town circumstances are changed by its proximity to Jerez' outstanding scale. The arrival of the autonomous winery building coincides with Jerez upcycle peak, when the economic impact of Jerez' sales boosted winemaking areas in all its vicinity due to the high demand. The autonomous winery began with the cloister and basilical models and has now evolved to the modern industrialized building (Figure 13). 


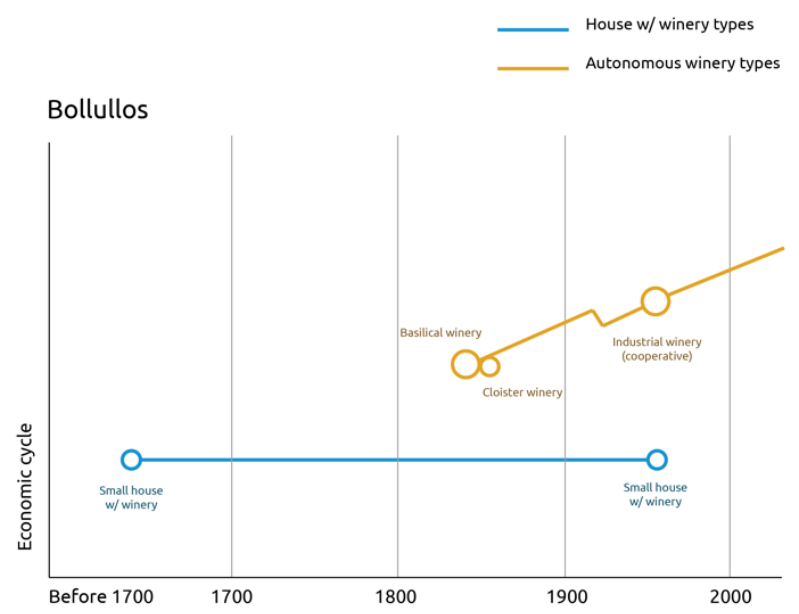

Figure 13. Chronological display of Bollullos' winery types, by typological line of evolution.

One additional element that is common to the three case studies is the constant rise in standardization of vernacular construction methods and materials, seen along the evolutionary line of either typology. The repetition of modules, done in order to achieve wider spaces, is common in both typologies, i.e., domestic or autonomous winery. Module repetition is based on the use of traditional techniques such as arches and vaults, making brick an important protagonist in these buildings. This use of vernacular techniques to achieve new conceptions of space, transitioning from Ancien Régime types to the industrial building, is probably one of the most important attributes of vernacular wineries. Regarding heritage values, it is this transitional aspect that makes wineries outstanding buildings, as they are one of the earlier architectonic examples of the arrival of the liberal and industrial age to the southern Iberian Peninsula.

\section{CONCLUSIONS}

Until the industrialization, be it in its early or late stages, wine is part of the vernacular house. Its production and storage are a household activity, as were the making and storage of olive oil or other animal food products. In time, and with trade development, the winery would progressively be detached from the house, and evolve typologically, at least since the 16th century, in parallel with other agriculture-support vernacular buildings. With the modernization begun in 18th century in leading winemaking regions like Jerez de la Frontera, the independent winery would go through a process of typological standardization, adapting itself to the industrial economical age through the optimization of space and material usage, and, especially, by growing in scale. The proximity to these cuttingedge places is one of the main factors behind the acceleration of industrialization processes, through the transference of knowledge, goods and funds from advanced regions to peripheral ones. Nevertheless, apart from exceptional cases such as Jerez, winemaking remains a wholly urban activity due to, in part, the intrinsic characteristic of vineyards' proximity to urban settlements.

Wine culture materialises in highly typified vernacular architectonic pieces, mainly due to their functional essence. Those can be medium to large houses with incorporated winery spaces or independent winery buildings. In the framework of vernacular architecture, these buildings stand out due to the use of traditional materials in functional, highly optimized, solutions; favouring modular and repetitive elements and open plan (and volume) spaces. Due to the fact they represent some of the vernacular architecture's examples with the highest optimization of space and material use, they remained a particularly relevant architectonic heritage, even after wine production moved out to 20th-century industrialized spaces.

Besides physical materialisation, centuries of winemaking have created a culture of social rites, norms and traditions in winetowns, many of those deeply rooted in socialization and fraternizing habits of working men, but also related to human and nature relations. In all these three cases, the winemaking activity was a fundamental part of the city's history and any part of this economic and cultural system takes on a strong heritage importance. Built typologies associated with wine offer a safeguard place to centuries-old knowledge and ethnographic values; more than their intrinsic architectonic value, they are part of a cultural heritage system of high significance.

When addressing future conservation and valorisation, it is important to consider the cultural system in its entirety. The economic and technological changes in winemaking have striped wine-related vernacular buildings of their use and new functions must be found to avoid demolitions. Building reuse has precedents in Marco de Jerez, with the accommodation of schools or social housing in the open plant wineries in the early 20th century. Nowadays, some former wineries shelter cultural organizations such as archive, library or neighbourhood associations. In Borba, adaptations have gone mainly towards housing. Considering the importance of wine-related buildings inside the urban settlements, given the amount of urban area these buildings occupy, it is crucial to keep their urban characteristics and presence. Strategies to achieve this are various and must be adequate to each case; nevertheless, the similarity between winemaking cities in terms of heritage context and challenges faced makes it useful and advisable to share their experiences and learn from one another. Transference of experiences in building and landscape preservation can be fomented through the creation of networks between European heritage wine cities, as it can contribute to a more effective valorisation of this common heritage.

\section{ACKNOWLEDGEMENTS}

The authors would like to thank the Fundação para a Ciência e Tecnologia (FCT) - Portugal and the HUM700 research group Universidad de Sevilla for the support given to this investigation.

\section{REFERENCES}

Aladro-Prieto, J. M., 2019. Bodegas, lagares y casas de viña Arquitectura, ciudad y paisaje del vino en Andalucía. $A H-$ Andalucía en la Historia, $\mathrm{n}^{\circ}$ 66, 14-17.

Aladro-Prieto, J. M., 2012. La construcción de la "Ciudad Bodega" - Arquitectura del vino y transformación urbana en Jerez de la Frontera en el Siglo XIX. PhD thesis. Universidad de Sevilla, Sevilla.

Aladro-Prieto, J. M., 2009. El viñedo de Jerez - arquitectura y paisaje del vino. $P H$ 69, 34-69.

Borrero Fernandéz, M., 1995. La viña en Andalucía durante la Baja Edad Media. Historia y Cultura del Vino en Andalucía, 33-61. 
Díaz, M. J. (coord.), 2003. Patrimonio Historico - Bollullos Par del Condado. Universidad de Huelva, Huelva.

Fourneau, F., 1975. El Condado de Huelva: Bollullos, capital del viñedo. Instituto de Estudios Onubenses, Huelva.

GTL Borba, 2001. O Vinho e o Património - Reflexos de uma cultura secular. Câmara Municipal de Borba, Borba.

Iglesias Rodríguez, J. J. (ed.), 1995. Historia y Cultura del Vino en Andalucía. Universidad de Sevilla, Sevilla

Maldonado Rosso, J., 2019. Los tres grandes cambios de la vinatería andaluza - la modernización de la vitivinicultura contemporánea. AH-Andalucía en la Historia, $\mathrm{n}^{\circ}$ 66, 8-13.

Olmedo Granados, F. (coord.) et al., 2002. Cortijos, haciendas y lagares arquitectura de las grandes explotaciones agrarias de Andalucía: provincia de Cádiz. Dirección General de Arquitectura y Vivienda, Sevilla.

Ribeiro, O., 1961. Geografia e Civilização - temas portugueses. Instituto de Alta Cultura Centro de Estudos Históricos, Lisboa.

Rosado, A. C., Reimão Costa, M., 2019. A arquitectura corrente no Alentejo: transformação da casa vitivinícola de Borba entre os sécs. XVII e XIX. Antologia de ensaios Laboratório Colaborativo: dinâmicas urbanas, património, artes, vol. 2, 43-60.

Simões, J. M., 2007. Borba - Património da Vila Branca. Colibri, Lisboa.

Zafra Costán, P. 2009. Mostos y Tabancos. Espacios de sociabilidad en la cultura tradicional jerezana. $P H$ 69, 63-67. 